Utah State University

DigitalCommons@USU

$5-2009$

\title{
Convergence and Divergence in Attachment Style Across Male and Female College Students' Friendships and Romantic Relationships
}

Victoria Jean Van Uitert

Utah State University

Follow this and additional works at: https://digitalcommons.usu.edu/honors

Part of the Psychology Commons

\section{Recommended Citation}

Van Uitert, Victoria Jean, "Convergence and Divergence in Attachment Style Across Male and Female College Students' Friendships and Romantic Relationships" (2009). Undergraduate Honors Capstone Projects. 7.

https://digitalcommons.usu.edu/honors/7

This Thesis is brought to you for free and open access by the Honors Program at DigitalCommons@USU. It has been accepted for inclusion in Undergraduate Honors Capstone Projects by an authorized administrator of DigitalCommons@USU. For more information, please contact digitalcommons@usu.edu.

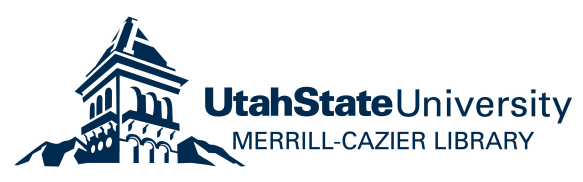




\title{
COVERGENCE AND DIVERGENCE IN ATTACHMENT STYLE ACROSS MALE AND FEMALE COLLEGE STUDENTS' FRIENDSHIPS AND ROMANTIC RELATIONSHIPS
}

\author{
by \\ Victoria Jean VanUitert \\ Thesis submitted in partial fulfillment \\ of the requirements for the degree \\ of \\ DEPARTMENTAL HONORS \\ in \\ Psychology \\ in the Department of Psychology
}

Approved:

Thesis/Project Advisor

Departmental Honors Advisor

(Renee Galliher, PhD.)

(Scott Bates, PhD.)

Director of Honors Program

(Christie Fox, PhD.)

UTAH STATE UNIVERSITY

Logan, UT

Spring 2009 
Running head: CONVERGENCE AND DIVERGENCE IN ATTACHMENT STYLE

Convergence and Divergence in Attachment Style across Male and Female College

Students' Friendships and Romantic Relationships

Victoria Jean VanUitert

Utah State University

Honors Thesis 


\begin{abstract}
Attachment representations in friendship and romantic relationship contexts were examined in a sample of 398 college students. Analyses examined patterns of attachment style in both relationship contexts, divergence and convergence in attachment style, and links between attachment representations and negative peer and romantic relationship experiences (i.e., relational and physical victimization and betrayal). The majority of participants reported more secure attachment representations, relative to preoccupied or dismissing attachment. However, analysis of biological sex indicated that males reported more dismissing attachment styles with both friends and romantic partners, relative to females. Additionally, significant links were observed between negative peer and romantic relationship experiences and attachment representations, in theoretically consistent directions.
\end{abstract}


Convergence and Divergence in Attachment Style across Male and Female College Students’ Friendships and Romantic Relationships

As a communal species, the role of the relationships formed by humans is important for social development. An element of relationships which is considered imperative to be able to achieve is intimacy (Collins \& Sroufe, 1999). Developing intimacy in a relationship is reliant on the experiences one engages in and the choices one makes. Collins and Sroufe (1999) argued that in order to obtain intimacy the person has to value closeness and be able to tolerate and express strong emotions within the context of to the relationship. These relationships give the individual the opportunity to learn what kinds of expectations they should have with regard to communicating with another person, as well as learn to accept the reactions from others (Collins \& Sroufe, 1999). However, many individuals encounter hardships in their relationships. Some face social victimization (e.g., bullying) while others are betrayed by their friends or romantic partners. How individuals perceive these events can affect how the course of that relationship goes (Fincham, 2001). Since these perceptions affect the relationship itself, it could also generalize into other kinds of relationships or future ones. In this study, these past events will be examined in relation to attachment style experiences.

\section{Attachment Theory}

In 1987, Hazan and Shaver explored the possibility of attachment theory being applied to adult romantic relationships. Hazan and Shaver (1987) theorized that the emotional bond developed between adult romantic partners shares a similar motivational system to the emotional bond between infants and their caregivers. Some parallels between adult and infant attachment include 1) both feel safe when the attachment figure is around and is responsive, 2) both engage in close, intimate bodily contact and 3) both feel insecure when the other person is not available 
(Hazan \& Shaver, 1987). Hazan and Shaver assessed attachment experiences among adult participants via self repot measures and observed that adult romantic representations could be adequately captured with the same attachment categories observed in parent-child attachment relationships: secure, avoidant, and anxious ambivalent. Further, attachment styles in adult participants followed similar patterns to those observed in the parent-child attachment literature; roughly $60 \%$ of participants were categorized as secure, $25 \%$ as avoidant, and $15 \%$ as anxious (Hazan \& Shaver, 1994). Finally, attachment representations in adult participants were linked to relationship experiences and relationship expectations in theoretically defensible ways.

A big part of attachment is intimacy. In order to be able to be intimate with another person, three things are necessary: first, be orientated towards and value closeness; second, the person must be capable of tolerating or even embracing intense emotions and expressing them freely, and third, one must be able to self-disclose, engage in mutual reciprocity, and be sensitive to and have concern for other's feelings (Collins \& Sroufe, 1999). The capacity for intimacy is theorized to develop from an integration of family and peer experiences in earlier stages of development (Furman \& Wehner, 1994; Shulman, Elicker, \& Stroufe, 1994). Although many believe attachment style to be stable throughout life, it has also been suggested that adult attachment is often thought of as being an accommodation between early attachment and current factors (Bowlby, 1973). In a four-year longitudinal study, Kirkpatrick and Hazan (1994) found that $70 \%$ of the participants had kept the same attachment style. To support this finding, Baldwin and Fehr (1995) concluded after reviewing the Kirkpatrick and Hazan study amongst others that $30 \%$ of people changed their attachment style over some amount of time.

Many studies have suggested that the relationships one has with friends, romantic partners, and family provide overlapping but distinct attachment related functions, such as 
providing a secure base from which to explore the world and serving as a support during distressing situations (Furman \& Buhrmester, 1992; Furman \& Wehner, 1994; Laursen \& Collins, 1994; Savin-Williams \& Berndt, 1990). Although the primary source of support for $4^{\text {th }}$ grade children was reported to be their parents, as children enter early/middle adolescence that relationship is somewhat supplanted by the relationships they form with same-sex peers. Parents are less likely to serve some important attachment functions, relative to same-sex friendships and romantic partners, as the child reaches college age (Furman \& Buhrmester, 1992). Friendships help older children and adolescents prepare for relationships amongst equals, learning such things as mutual disclosure and how to gain emotional gratification (Collins, 1996). Romantic relationships are seen, in a developmental perspective, as being part of what motivates people to form and maintain close relationships (Baumeister \& Leary, 1995) and comes from a progression of relationships throughout life (Ainsworth, 1989; Feeney \& Noller, 1990; Furman \& Wehner, 1994) In fact, Collins and Sroufe (1999) suggested that the early parent-child relationships, peer relationships formed during preschool and middle childhood, and close friendships during adolescence contribute to how one behaves or reacts emotionally to a romantic relationship.

\section{Relational Views}

Furman and Wehner (1994) coined the term "views" to describe attachment related belief systems about important relationships with family, friends, and romantic partners. They define views as the unconscious and conscious perceptions one holds about themselves and their relationship partners, as well as the relationship itself. Furman and Wehner (1994) also suggested that these views are formed through not only the interactions and experiences of the current relationship, but also the experiences one has had from previous relationships. Though views of a particular type of relationship (e.g., friendships) are theorized to be influenced by other types of 
relationships (e.g., parent-child relationships or romantic relationships), different relationships are not expected to share identical views due to the fact that they are influenced strongly by the experiences of an individual person. People enter into relationships with preconceptions and expectations for the relationship based off of past experience, primarily in similar relationships and secondarily in other types of relationships they have had (Furman \& Wehner, 1994). These preconceptions and expectations shape how one acts and may lead to fulfilling their expectations (Snyder, Tanke, \& Berscheid, 1977). If these expectations are not met, they may gradually be altered (Furman \& Wehner, 1994). Past romantic relationship experiences, as well as the relationships with others are highly likely to impact the quality of emerging romantic relationship "views" (Furman \& Wehner, 1994). Thus, while "views" of different types of relationships might be expected to be similar, based on the cumulative relational experiences the individual has had, distinctions may emerge in the attachment representations of different types of relationships (e.g., friendships vs. romantic relationships).

\section{Maladaptive Platonic and Romantic Experiences}

Peer victimization has been described as repeated exposure to negative events (such as verbal abuse or unwanted physical contact) from another person (Olweus, 1993). Researchers have found a number of negative experiences correlated with being victimized; including anxiety, depression, loneliness, and lower self-esteem (Bagwell, Newcomb, \& Bukowski, 1998; Boivin \& Hymel, 1997; Bond, Carlin, Thomas, Rubin \& Patin, 2001; Crick \& Bigbee, 1998). Severe psychopathology such as eating disturbances and features of borderline and antisocial personality disorders in young adults have also been linked to victimization experiences (Werner \& Crick, 1999). Crick and Ladd (1993; Ladd \& Crick, 1989) suggested that early perceptions and feelings people have of social situations develop over time through their social interactions. 
People whose experiences of victimization had ended reported that the cessation of victimization did not necessarily mitigate feelings of loneliness or lack of social satisfaction (KochenderferLadd \& Wardrop, 2001). Instead, these early experiences have been shown to be related with social phobia in adults (McCabe, Antony, Summerfeldt, Liss \& Swinson, 2003). This aversion towards others' evaluations often leads to feelings of anxiety in social situations. Researchers have suggested this is due to poor past experiences one had. This can lead the person to develop a negative image of themselves through their assumptions of how others perceive them (Hackmann, Clark, \& McManus, 2000).

Research has also shown that relationship quality with peers can influence later romantic relationships (Linder, Crick, \& Collins, 2002). It has been shown repeatedly that poor peer relations have been linked to psychological and physical victimization among women later in life; even marital violence (O’Leary, Malone, \& Tyree, 1994; Sharpe \& Taylor, 1999). For example, in distressed couples, insecure members of a couple tended to view the other person's behavior in a way that enhanced the distress they were experiencing (Johnson, Makinen, \& Millikin, 2001). The insecure member of the relationship may also take minor disappointments in their current relationship and turn them into something bigger, often attributing the little things as a reflection of past wrongs that had happened to them. This negative view of their relationship eventually could lead to the members of the unhappy couple to only remember the negative aspects of the relationship. Combining the elements of adhering to a negative schema about their relationship and escalating small issues into a major problem due to past experience, it has been suggested that future actions engaged in by either individual could lead to the other feeling like a "hostage" in their relationship (Johnson, Makinen, \& Millikin, 2001). Due to this, it seems 
reasonable to conceptualize that negative events (e.g., abandonment or betrayal) can cause a significant amount of damage to close relationships (Johnson et al., 2001). Developmental Change and Convergence vs. Divergence

There has been much speculation as to why attachment style may not be convergent across different important relationships. Furman and Wehner (1998) theorized that experience differentially affects attachment style in different types of relationships. In addition to this, they said that individuals' views in their relationships are open to change depending on the experiences they have. Expectations also play a role in the development of certain views about a relationship. If one's expectations differ from what actually occurs in a relationship, it can change their view of that particular type of relationship (Furman \& Wehner, 1998). Kirkpatrick and Hazan (1994) suggested that perhaps one's romantic attachment style might change due to a change in the functioning of the relationship, but Baldwin and Fehr (1995) found that attachment style did not necessarily change when the romantic relationship status did. In a recent study, it was found that some people are just more prone to attachment style change than others (Davila, Burge, \& Hammen, 1997). According to their findings, people who are more prone to attachment style change are more likely to have attachment insecurity and psychopathology. Davila, Burge, and Hammen (1997) proposed that women who change their attachment style may have tentative views of others and themselves. These individuals may question their self-worth, how much they can really trust others, and how comfortable they are with being intimate with others. These women also have been found to more likely be stably insecure than stably secure.

\section{Summary and Research Questions}

This study examined the phenomenon of attachment style representations and the concordance and discordance between platonic and romantic relationships. As has been 
suggested, these differing attachment styles overlap and past relationships affect emerging ones. The study examined associations between such things as peer-victimization, experiences of dating aggression, and betrayal and attachment styles across friendships and romantic relationships, as the views of these particular relationship types are likely differentially associated with these experiences. The following research questions were addressed:

1. What are the patterns of friendship and romantic relationships attachment representations among college students?

2. To what extent are attachment representations for friendship and romantic relationships convergent and divergent?

3. How are reported negative experiences in past peer and romantic relationship contexts related to attachment representations in friendships and romantic relationships?

Methods

\section{Participants}

Participants were 398 undergraduate student-volunteers, age 17-45, who were enrolled in psychology courses at Utah State University. Females represented $66 \%$ of the sample. Of the sample, $90.4 \%$ of participants were Caucasian and $82.8 \%$ were members of the Church of Jesus Christ of Latter-day Saints. Approximately half (50.1\%) of participants were freshmen and over $50 \%$ of participants were between 18 or 19 (33\% were 18 and $20.4 \%$ were 19$) .35 .3 \%$ of participants were single, $27.7 \%$ were casually dating, $20.9 \%$ reported being in a serious relationship, 3.8\% were engaged, and $0.8 \%$ were divorced. These students were recruited from both introductory and advanced psychology courses. 


\section{Measures}

Behavioral Systems Questionnaire: The Behavioral Systems Questionnaire (BSQ)

(Wehner \& Furman, 1999) is a 65-item measure assessing attachment, caregiving, and affiliation experiences in relationships with parents, romantic partners, and friends. An additional scale addresses physical/sexual behavior in romantic relationships. For the purpose of this study, the 15-item attachment scale was used to assess attachment representations with romantic partners and friends. Respondents earn scores for each of three attachment categories, based upon the behavioral styles of secure, dismissing, and preoccupied. Sample items in this portion of the BSQ include "I seek my romantic partner/friend when something bad happens", "I do not ask my romantic partner/friend to comfort me", and "My romantic partner/friend acts as if I count on them too much" for secure, dismissing, and preoccupied respectively. Scoring is also based on a 5-point Likert scale where "1" equals "Strongly Disagree" to and "5" equals "Strongly Agree." Items within a subscale are summed to create a total score. For the attachment, caregiving, and affiliation scales, a mean alpha $=.89$ (range .84 to .94) was found in previous research (Flanagan \& Furman, 2000).

In this study, three scores for romantic and three for platonic relationships were calculated through using the 15 -item attachment scale. Secure romantic attachment yielded an alpha of 0.87 , dismissing had an alpha of 0.84 , and preoccupied yielded an alpha of 0.83 . Alphas for secure, dismissing, and preoccupied styles in platonic relationships were $0.87,0.84$, and 0.85 respectively.

Self-Report of Aggression \& Social Behavior Measure. The Self-Report Measure of Aggression and Victimization (SRMAV) (Linder, Crick, \& Collins, 2002; Morales \& Crick, 1998) is a 56-item questionnaire with subscales for relational aggression, physical aggression, 
relational victimization, physical victimization, exclusivity, and pro-social behavior. Within each domain, separate scores are calculated for experiences in peer relationships and experiences in romantic relationships. Respondents use a 7-point Likert scale with " 1 " being equivalent to "Not at all true" and "7" being equivalent to "Very true". Previous research using subscales from this measure have obtained adequate reliability (i.e., above .70). Alphas were assessed for the seven subscales that were utilized for this study. Two separate scores were obtained for the relational victimization, physical victimization, and exclusivity representing experiences for both friendship and romantic relationships. Romantic and platonic relational victimization scales yielded alphas of 0.82 and 0.74 respectively. Physical victimization scales resulted in an alpha of 0.63 for romantic relationships and 0.69 for platonic relationships. Romantic exclusivity showed an alpha of 0.79 and friendship exclusivity yielded 0.67 . General prosocial behaviors had an alpha of 0.83 .

Betrayal Questionnaire. The Betrayal Questionnaire is a 24-item measure designed for the purpose of this study. Items were developed to assess betrayal experiences with friends and romantic partners. Questions asked on this survey tapped common potential relationship issues that could be related to feeling betrayed. Examples include "has your friend ever put you down?" and "has your romantic partner ever cheated on you with another romantic partner?" Items are rated on a 5-point Likert scale with " 1 " being equivalent to "Never" and " 5 " being equivalent to “Many time/Often". Alphas were 0.88 for friendship betrayal and 0.91 for relationship betrayal.

\section{Procedure}

Students were informed of the opportunity to participate in the current study through announcements in their psychology courses as well as notices posted on the class websites. Participation in this study was used by the students as one of many ways they could receive 
course credit for lab requirements. Participants completed the survey online at their convenience. Before being allowed to do the survey, participants were sent to an informed consent form page. The participants were told that some survey items address personal issues and potentially emotion-triggering relational experiences. Participants who consented to participate clicked a button labeled "continue" to be forwarded to the survey. All data entered were encrypted for secure transmission.

Upon completion, participants were prompted to close the page so third party individuals would not see their information. There was a link to a separate survey where participants submitted their names and instructors' names to receive credit for participating.

Results

\section{Patterns of Attachment Representation}

Table 1 presents means and standard deviations for males and females for the three attachment style scales for both friendships and romantic relationships. Two mixed two-way analyses of variance (ANOVA) were calculated. In the first ANOVA, scores on the secure, dismissing, and preoccupied scales for romantic relationships were used as a repeated measure, and biological sex was used as a between subjects factor. There was a significant main effect for attachment style, $F(2,770)=193.63, p<.001, \eta^{2}=0.34$. Overall, participants reported higher secure attachment scores than dismissing, and higher dismissing scores than preoccupied. All pairwise comparisons were significant. Additionally, while there was no significant main effect for biological sex, $F(1,385)=2.01, p=.157, \eta^{2}=0.005$, there was a significant interaction between biological sex and attachment style, $F(2,770)=26.60, p<.001, \eta^{2}=0.07$ (see Figure 1). Males demonstrated higher dismissing scores than females, while females demonstrated higher secure attachment scores than males. 
Similarly, for the second ANOVA, the repeated factor was comprised of secure, dismissing, and preoccupied scores within the friendship context, and biological sex was the between subjects factor. Results showed no significant main effect for biological sex, $F(1,387)=$ 96. $p=.328, \eta^{2}=0.002$. However, a significant main effect for attachment scale was observed, $F(2,774)=190.12, p<.001, \eta^{2}=0.33$, and the pattern of pairwise comparisons was the same as the main effect for romantic attachment style. Finally, a significant interaction was observed between biological sex and the attachment style, $F(2,774)=26.63, p<.001, \eta^{2}=0.06$ (see Figure 2). The pattern of interaction was the same as the pattern observed for romantic attachment scores.

Participants were also categorized as dismissing, preoccupied, or secure in both friendship and romantic relationship contexts, based on the highest score achieved on the three BSQ attachment domains. Undifferentiated individuals were those who had two or more scores which were equivalent to each other. Two chi square tests of independence evaluated the relative proportions in each attachment category for males and females for each relationship type. For romantic partner attachment representations, a significant chi square indicated that the distribution of attachment categories was not the same for males as it was for females, $\chi^{2}(3, \mathrm{~N}=$ $387)=23.93, p<.001, \mathrm{~V}=.25$. Males were overrepresented in the dismissing attachment category, while females were over represented in the secure attachment category (see Table 2). The chi square analysis examining friendship attachment categories was also significant, $\chi^{2}(3, \mathrm{~N}$ $=389)=32.94, p<.001, \mathrm{~V}=.29$, indicating that the proportion of attachment categories differed for males and females. Again, males were overrepresented in the dismissing category and females were overrepresented in the secure category. 


\section{Convergence and Divergence in Attachment Representations}

Convergence and divergence in attachment style between friendships and romantic relationships was examined via a crosstabs analysis that summarizes the frequency of converging and diverging patterns of attachment. Table 3 demonstrates the patterns of attachment categorization. Several cells in this crosstabs matrix did not meet the assumption of at least five expected observations in each cell necessary for a chi square test of independence. However, a cautiously interpreted chi square analysis did demonstrate a significant relationship between friendship and romantic attachment styles, $\chi^{2}(9, \mathrm{~N}=386)=72.43, p<.001, \mathrm{~V}=.25$. Of the participants, 231 ( $60 \%$ of the sample) were convergent in their attachment styles; and $47 \%$ of the sample was convergent secure. Of those who were divergent, the majority were secure in either friendships or romantic relationships and dismissing or undifferentiated in the other relationship type.

\section{Links between Previous Relationship Experiences and Attachment Representations}

Tables 4 and 5 demonstrate the correlations between relational experiences and attachment styles in both romantic and platonic relationships of males and females respectively. The pattern of significant correlations among male participants appears to be rather diffused; showing that negative experiences in platonic and romantic relationships are linked to attachment scores in both relationship types. However, the majority of peer and romantic experiences of victimization and betrayal appear to be strongly related to male preoccupied attachment style in both romantic and platonic relationships (see Table 4).

Significant correlations for females were shown to be concentrated on the table in three ways. First, negative romantic experiences and romantic exclusivity were strongly associated with the three romantic attachment styles for women, in theoretically consistent directions. 
Second, similar to males, females who reported high levels of either romantic or platonic preoccupied attachment style engagement had more significant correlations with both romantic and platonic negative relational experiences and betrayal. Third, scores for females on all of the romantic and friend attachment scales were significantly correlated to the pro-social scale in expected directions (see Table 5).

Two sets of one-way ANOVAs were calculated exploring the differences between attachment style categories on both romantic and platonic relational experiences (see Tables 6 and 7). Significant differences between the friendship attachment style categories were found for five of the nine relational experiences measured by the SRMAV. Generally, individuals who scored highest for preoccupied attachment reported higher levels of negative relationship experiences but lower levels of pro-social behaviors than those who were secure, dismissing, or undifferentiated (see Table 6).

Seven of the nine ANOVAS examining differences between the romantic attachment categories on the SRMAV scales were significant. Individuals who scored highest on preoccupied attachment appear to report the most exclusivity in both types of relationships as well as high levels of friend betrayal. Individuals who were undifferentiated reported engaging in lower amounts of pro-social behaviors than those who fell into the three other attachment style categories.

\section{Discussion}

The purpose of this study was to explore links between attachment representations and experiences of victimization and betrayal in platonic and romantic relationships. Research questions investigated patterns of friendship and romantic relationship attachment among college 
students, levels of convergence and divergence in friend and romantic attachment styles, and associations between experiences of betrayal and victimization and attachment styles.

\section{Overall Attachment Patterns}

Similar to the findings of Hazan and Shaver (1994), data from this study suggested that the majority of participants reported being secure in their romantic relationships. Many studies over the years have explored attachment styles in romantic relationships, but none were identified that assessed attachment representations in friendships, and none have compared romantic attachment styles with platonic relationship attachment styles. Research has shown the importance of friendships early in life for the development of intimacy with others, and platonic peers have been posited to serve as primary attachment figures during adolescence and the transition to adulthood (Furman \& Wehner, 1994; Shulman, Elicker, \& Stroufe, 1994). It is not surprising that these friendships may continue to play a predominant attachment role into adult years. Friendship relationships may always have the capacity to serve as a learning context for people to gain better insight as to how to interact and bond with others. This study offers a foundation for exploring the friendship attachment experiences of adults.

There were some interesting sex differences observed in this study. Females reported to be predominantly secure in attachment style while males reported higher scores on dismissing attachment scales. Male and female scores did not particularly differ in preoccupied scores. This has some implications related to how both genders are socialized. Females are generally raised to be more emotionally in tune and expressive about their relationships with others, while male gender role stereotypes are more taciturn regarding expression of feelings and emotions. This lack of expression could possibly be associated to the reports of detachment in their relational attachment styles with others. 


\section{Convergence \& Divergence}

While $70 \%$ of the sample reported secure romantic attachment and $60 \%$ reported secure friendship attachment, only $47 \%$ reported being convergent secure (i.e., secure in both types of relationship). Although the number of individuals who identified as secure in both relationship types was consequential, the majority (53\%) of participants had at least one insecure attachment style in regard to their relationships with friends and romantic partners. Having over half of the 398 people reporting some form of insecurity in their relationships suggests that there is a need for a form of intervention in order to aid them to have more secure styles of attachment in relation to their peers and romantic partners. Future research will have to investigate what approaches may benefit insecure individuals to have more confidence and ease in communicating with individuals in either or both contexts.

It would also be of interest how other variables, such as personality and culture, influence the divergent attachment styles experienced by 155 (or $40 \%$ ) of the participants as well. Studies in the future will need to evaluate how cultural scripts for how to interact and bond with romantic partners differ from peers. Personality easily could also influence how a person attaches to another. Some individuals may have a tendency to be avoidant by nature and are completely content with this. It would be interesting to see if the five traits of the 5-factor personality test yield significant differences in scores between the three attachment styles and also the prevalence of relational experiences explored by the SRMAV.

\section{Attachment Styles and Relationship Experiences}

The findings from this study seem to complement attachment theory predictions. For example, the exclusivity score assesses the level of dependence felt towards their significant other (e.g., close friend or romantic partner). Preoccupied individuals demonstrated the highest 
positive correlation with exclusivity among the three styles. This is not surprising considering that this attachment style is often characterized as the person being "clingy" or dependent on their partner or friend for happiness.

Correlation results also have interesting implications about both general attachment style research and gender socialization research. Supporting the classic definitions of attachment styles, those who reported the highest levels of secure attachment had scores associated with lower negative relational experiences and higher engagement of pro-social behaviors. This result is supported by Collins and Sroufe (1999) who said that children who displayed a secure attachment style never were the bully or the victim. Instead, children who are predominantly secure report more self-reliance and better peer relationships (Collins \& Sroufe, 1999).

Rawlins (1992) suggested that men tend to make fewer distinctions between romantic relationships and cross-sex friendships than women do (Reeder, 1996). While males have a tendency to group cross-sex friendships and romantic relationships together separating same sex friends, females, on the other hand, group same and cross-sex friendships together versus romantic relationships (Rawlins, 1992; Reeder, 1996). This was supported in a study where, although most males and females agreed they wanted to remain platonic friends, the rest of the females believed their male friend wanted more from the relationship than they did while the rest of the males primarily agreed with those females' assessment and a couple of the males believed that the female was interested in them (VanUitert, 2009). In the current study, it is believed that the diffusion of significant correlations shown in males' relationship experience and attachment scores may also be portraying this ambiguity in their friendships. However, it is hard to be certain why exactly males' significant correlations are scattered across the possible combinations on the table. In this study, participants were not asked if they were thinking of a male or female 
friend while answering the attachment questions. It would be imperative to investigate if there are differences in participants' views of same and cross-sex peers, and how those compare to views of romantic partners.

\section{Conclusions and Limitations}

Results from this study suggest that many negative relationship experiences are significantly linked to the way males and females represent attachment in important relationships. This was especially clear for individuals who were high on preoccupied attachment, who showed the most significant correlations with these experiences. Due to the nature of these findings, it is curious that these relationship events were so importantly linked to preoccupied attachment representations. It would be interesting to see how friendship and romantic relationship experiences are related to their self-efficacy and to know how long these experiences actually lasted. Although they reported either the most strongly positive or negative correlations between their attachment style and experiences, does this really mean that they had any more or less occurrences of victimization and betrayal than secure and dismissing individuals or is it how they perceive and apply their experiences? Longitudinal studies will need to be administered assessing childhood experiences of peer victimization and betrayal and compare it to scores these individuals yield in adolescence and adulthood. Tracking reports participants give across time will allow us to see if there is a correlation between relational experiences over the lifespan with the attachment behaviors engaged in as adults. Also, by examining scores over a longer span of time, it will give us the opportunity to examine if there are differing levels of victimization and betrayal reported at different developmental stages. This would permit us to evaluate if one's perceptions may be more strongly correlated with reports of 
victimization than the actual frequency. It would also be interesting to assess how evidence of a psychological disorder such as depression or anxiety may influence these perceptions as well.

Secure individuals are often characterized as having a good self-esteem and effective relations with peers. These individuals were also shown to have fewer experiences of victimization and betrayal. Since there seems to be a considerable increase of victimization events and a decrease of pro-social behaviors among insecure individuals, particularly preoccupied ones, interventions utilizing social skill development and mindfulness could prove to be beneficial. Social skill interventions may help increase the amount of pro-social behaviors in these individuals which may also aid them in feeling more confident and amplify feelings of self-efficacy. Since it is possible that the reports of negative relational experiences are due to the perceptions held by particular attachment style groups, mindfulness offers them another, more objective, way of looking at things. Perception can be very potent in regards to how emotional attributions are made and thought processes are created. Challenging negative thoughts or beliefs about situations one comes across may help insecure individuals cope better with what they encounter.

A limitation in this study was how small the number of individuals who reported to be preoccupied was among both males and females. Literature says that roughly $15 \%$ of individuals demonstrate a preoccupied attachment style and this is not shown in this data set. It would be interesting to obtain a larger sample size and see if the significance found in the number of individuals we do have is repeated with more people labeled as preoccupied. Another limitation is in regards to where this study was administered. The participating community is predominantly a non-Hispanic white and LDS area. Because of this, it is questionable if these 
results can be generalized to other ethnicities and cultures. Future studies will need to explore these attachment styles and relational experiences in other cultures and regions. 


\section{References}

Ainsworth, M.D.S. (1989). Attachments beyond infancy. American Psychologist, 44, 709-716.

Bagwell, C. L., Newcomb, A. F., \& Bukowski, W. M. (1998). Preadolescent friendship and peer rejection as predictors of adult adjustment. Child Development, 69, 140-153.

Baldwin, W. M., \& Fehr, B. (1995). On the instability of attachment style ratings. Personal Relationships, 2, 247-261

Baumeister, R.F. \& Leary, M.R. (1995). Te need to belong: Desire for interpersonal attachments as a fundamental human motive. Psychological Bulletin, 117, 497-529.

Bowlby, J. (1973) Attachment and Loss Vol 2: Separation, anxiety and anger, New York, Basic Books.

Collins, W.A. (1996). Relationships and development during adolescence: Interpersonal adaptation to individual change: Personal Relationships, 3, 308-318.

Collins, W.A. \& Sroufe, L.A. (1999). Capacity for Intimate Relationships: A Developmental Construction. In W. Furman, B.B. Brown \& C.

Crick, N. R., \& Bigbee, M. A. (1998). Relational and overt forms of peer victimization: A multiinformant approach. Journal of Consulting and Clinical Psychology, 66, 337-347.

Crick, N.R., \& Ladd, G.W., (1993). Children's perceptions of their peer experiences: Attributions, loneliness, social anxiety, and social avoidance, Developmental Psychology, 29, 244-254.

Davila, J., Burge, D., \& Hammen, C. (1997). Why does attachment style change? Journal of Personality and Social Psychology, 73, 826-838.

Feeney, J.A. \& Noller, P. (1990). Attachment style as a predictor of adult romantic relationships. Child Development, 63, 103-115.

Fincham, F.D. (2001). Attributions in close relationships: From balkanization to integration. In G.J.O. Fletcher \& M.S. Clark (Eds.), Blackwell handbook of social psychology: Interpersonal processes, 3-31. Oxford, England: Blackwell.

Flanagan, A. S., \& Furman, W. C. (2000). Sexual victimization and perceptions of close relationships in adolescence. Child Maltreatment, 5, 350-359.

Furman, W. \& Buhrmester, D. (1992). Age and Sex in Perceptions of Networks of Personal Relationships. Child Development, 63, 103-115. 
Furman, W. \& Wehner, E.A. (1994). Romantic views: Toward a theory of adolescent romantic relationship. In R. Montemayor (Ed), Advances in adolescent development, Vol. 3: Relationship in adolescence. Beverly Hills, CA.

Furman, W., \& Wehner, E.A. (1998). Adolescent romantic relationships: A developmental perspective. In S. Shulman \& W.A. Collins (Eds.), New directions for child development: Adolescent romantic relationships. San Francisco, CA: Jossey-Bass.

Hackmann, A., Clark, D.M., McManus, F. (2000). Recurrent images and early memories in social phobia. Behaviour Research and Therapy, 38, 601-610.

Hazan, C., \& Shaver, P. R. (1987). Romantic love conceptualized as an attachment process. Journal of Personality and Social Psychology, 52, 511-524.

Hazan, C., \& Shaver, P.R. (1994). Attachment as an Organizational Framework for Research on Close Relationships. Psychological Inquiry, 5, 1-22

Johnson, S.M., Makinen, J.A., \& Millikin, J.W. (2001). Attachment injuries in couple relationships: A new perspective on impasses in couples therapy. Journal of Marriage and Family Therapy, 27,145-155.

Kochenderfer-Ladd, B., \& Wardrop, J.L. (2001). Loneliness and social satisfaction growth curves of children who are victimized by peers. Child Development, 72, 134-151.

Kirkpatrick, L.A. \& Hazan, C. (1994). Attachment Styles and Close Relationships: A Four-Year Prospective Study. Journal of Personality and Social Psychology, 66, 502-512.

Ladd, G.W., \& Crick, N.R. (1989). Probing the psychological environment: Children's cognitions, perceptions and feelings in the peer culture. In C. Ames \& M. Haehr (Eds.), Advances in motivation and achievement, pp. 1-44. Greenwich: JAJ.

Laursen, B. \& Collins, W. A. (1994). Interpersonal conflict during adolescence. Psychological Bulletin, 115, 197-209.

Linder, J.R., Crick, N.R., \& Collins, W.A. (2002). Relational Aggression and Victimization in Young Adults' Romantic Relationships: Associations with Perceptions of Parent, Peer, and Romantic Relationship Quality. Social Development, 11, 71-86.

McCabe, R.E., Antony , M.M., Summerfeldt, L.J., Liss, A., \& Swinson, R.P. (2003). A preliminary examination of the relationship between anxiety disorders in adults and selfreported history of teasing or bullying experiences. Cognitive Behaviour Therapy, 32, 187-193.

Morales, J.R. \& Crick, N.R. (1998). Self-report measure of aggression and victimization. Unpublished measure. 
Olweus, D. (1993). Bully/victim problems among schoolchildren: Long-term consequences and an effective intervention program. In S. Hodgins (Ed.), Mental Disorder and Crime, . Thousand Oaks, CA: Sage Publications. 317-349.

Rawlins, Friendship matters. New York: Aldine de Gruyter.

Reeder, H.M. (1996). What Harry and Sally don't tell you: The subjective experience of heterosexual cross-sex friendships. Unpublished doctoral dissertation. Arizona State Univesity, Tempe, AZ.

Savin-Williams, R. C., and Berndt, T. J. (1990). Friendships and Peer Relations during Adolescence. In S. S. Feldman and G. R. Elliott (Eds.), At the Threshold: The Developing Adolescent. Cambridge, MA: Harvard University Press.

Shulman, S., Elicker, J., \& Sroufe, L.A. (1994). Stages of friendship growth in preadolescence as related to attachment history. Journal of Social and Personal Relationships, 11, 341-361.

Snyder, M., Tanke, E.D., \& Berscheid, E. (1977). Social perception and interpersonal behavior: On the self-fulfilling nature of social stereotypes. Journal of Personality and Social Psychology, 33, 656-666.

VanUitert, V. (2009, April). Associations between nonverbal behavior and self-reported perceptions in cross-sex friendships. Paper presentation at the $79^{\text {th }}$ Annual Rocky Mountain Psychological Association Conference, Albuquerque, NM.

Wehner, E.A. \& Furman, W. (2000) The Behavioral Systems Questionnaire. Unpublished manuscript.

Werner, N., \& Crick, N. (1999). Relational aggression and social-psychological adjustment in a college sample. Journal of Abnormal Psychology, 108, 615623. 
Table 1

Male and Female Means for Attachment Scores in Friend and Romantic Relationships

\begin{tabular}{lccc}
\hline & Secure & Dismissing & Preoccupied \\
\hline Male & & & \\
\hline Friend Score & $3.02(0.83)$ & $3.08(0.74)$ & $1.95(0.72)$ \\
Romantic Partner Score & $3.30(0.83)$ & $2.86(0.75)$ & $2.19(0.78)$ \\
\hline Female & & & \\
\hline & & & \\
Friend Score & $3.54(0.82)$ & $2.61(0.90)$ & $2.02(0.72)$ \\
Romantic Partner Score & $3.80(0.82)$ & $2.38(0.79)$ & $2.33(0.81)$ \\
\hline
\end{tabular}


Table 2

Frequencies of Attachment Style Categories for Males and Females N (\%)

\begin{tabular}{rcccc}
\hline & Secure & Dismissing & Preoccupied & Undifferentiated \\
\hline Male & & & \\
\hline Friend Score & $50(38 \%)$ & $61(47 \%)$ & $6(5 \%)$ & $13(10 \%)$ \\
Romantic Partner Score & $69(54 \%)$ & $36(28 \%)$ & $6(5 \%)$ & $17(13 \%)$ \\
\hline Female & & & & $11(4 \%)$ \\
\hline Friend Score & $178(69 \%)$ & $64(25 \%)$ & $6(2 \%)$ & $18(7 \%)$ \\
\hline
\end{tabular}


Table 3

Patterns of Attachment Categories in Friendships and Romantic Relationships $(N=386)$

\begin{tabular}{llrrrr}
\hline & \multicolumn{5}{c}{ Friend Attachment Category } \\
\cline { 3 - 6 } & & Secure & Dismissing & Preoccupied Undifferentiated \\
\hline Romantic & Secure & 181 & 66 & 5 & 18 \\
\cline { 2 - 6 } $\begin{array}{l}\text { Attachment } \\
\text { Category }\end{array}$ & Dismissing & 21 & 42 & 2 & 2 \\
\cline { 2 - 6 } & Preoccupied & 5 & 5 & 4 & 0 \\
\cline { 2 - 6 } & Undifferentiated & 21 & 9 & 1 & 4 \\
\hline
\end{tabular}


Table 4

Bivariate Correlations between Attachment Scores and Relationship Experiences for Males

\begin{tabular}{lcccccc}
\hline & $\begin{array}{l}\text { Secure } \\
\text { (Romantic) }\end{array}$ & $\begin{array}{l}\text { Dismissing } \\
\text { (Romantic) }\end{array}$ & $\begin{array}{l}\text { Preoccupied } \\
\text { (Romantic) }\end{array}$ & $\begin{array}{l}\text { Secure } \\
\text { (Friend) }\end{array}$ & $\begin{array}{l}\text { Dismissing } \\
\text { (Friend) }\end{array}$ & $\begin{array}{l}\text { Preoccupied } \\
\text { (Friend) }\end{array}$ \\
\hline $\begin{array}{l}\text { Romantic } \\
\text { relational } \\
\text { victimization }\end{array}$ & -0.07 & 0.04 & $0.25 * *$ & -0.01 & -0.03 & 0.15 \\
\hline $\begin{array}{l}\text { Romantic } \\
\text { physical } \\
\text { victimization }\end{array}$ & $-0.19 *$ & -0.01 & 0.13 & -0.13 & 0.04 & $0.22 *$ \\
\hline $\begin{array}{l}\text { Romantic } \\
\text { exclusivity }\end{array}$ & 0.13 & -0.18 & $0.43^{* *}$ & -0.08 & 0.09 & 0.17 \\
\hline $\begin{array}{l}\text { Romantic } \\
\text { Betrayal }\end{array}$ & 0.03 & -0.03 & 0.17 & 0.12 & -0.05 & 0.17 \\
\hline $\begin{array}{l}\text { Friend } \\
\text { relational } \\
\text { victimization }\end{array}$ & -0.17 & 0.08 & $0.25 * *$ & 0.12 & -0.05 & $0.25 * *$ \\
\hline $\begin{array}{l}\text { Friend } \\
\text { physical } \\
\text { victimization }\end{array}$ & $-0.26 * *$ & $0.18 *$ & 0.03 & 0.05 & -0.03 & 0.10 \\
\hline $\begin{array}{l}\text { Friend } \\
\text { exclusivity }\end{array}$ & 0.04 & -0.12 & $0.48 * *$ & 0.12 & -0.09 & $0.41 * *$ \\
\hline $\begin{array}{l}\text { Friend } \\
\text { betrayal }\end{array}$ & -0.10 & 0.03 & $0.22 *$ & 0.14 & -0.09 & $0.34 * *$ \\
\hline $\begin{array}{l}\text { Pro-social } \\
\text { behaviors }\end{array}$ & 0.12 & 0.73 & -0.13 & $0.24 * *$ & -0.04 & $-0.19 *$ \\
\hline & & & & & & \\
\hline
\end{tabular}


Table 5

Bivariate Correlations between Attachment Scores and Relationship Experiences for Females

\begin{tabular}{|c|c|c|c|c|c|c|}
\hline & $\begin{array}{l}\text { Secure } \\
\text { (Romantic) }\end{array}$ & $\begin{array}{l}\text { Dismissing } \\
\text { (Romantic) }\end{array}$ & $\begin{array}{l}\text { Preoccupied } \\
\text { (Romantic) }\end{array}$ & $\begin{array}{l}\text { Secure } \\
\text { (Friend) }\end{array}$ & $\begin{array}{l}\text { Dismissing } \\
\text { (Friend) }\end{array}$ & $\begin{array}{l}\text { Preoccupied } \\
\text { (Friend) }\end{array}$ \\
\hline $\begin{array}{l}\text { Romantic } \\
\text { relational } \\
\text { victimization }\end{array}$ & $-0.19 * *$ & $0.17 * *$ & $0.26 * *$ & -0.02 & -0.01 & $0.19 * *$ \\
\hline $\begin{array}{l}\text { Romantic } \\
\text { physical } \\
\text { victimization }\end{array}$ & $-0.14 *$ & 0.11 & $0.19 * *$ & -0.02 & 0.004 & 0.03 \\
\hline $\begin{array}{l}\text { Romantic } \\
\text { exclusivity }\end{array}$ & $0.17 *$ & $-0.16 *$ & $0.26 * *$ & -0.06 & 0.07 & 0.02 \\
\hline $\begin{array}{l}\text { Romantic } \\
\text { Betrayal }\end{array}$ & -0.06 & 0.05 & $0.24 * *$ & 0.01 & -0.03 & 0.09 \\
\hline $\begin{array}{l}\text { Friend } \\
\text { relational } \\
\text { victimization }\end{array}$ & -0.003 & 0.03 & 0.07 & 0.02 & 0.04 & $0.14 *$ \\
\hline $\begin{array}{l}\text { Friend } \\
\text { physical } \\
\text { victimization }\end{array}$ & -0.07 & 0.05 & 0.12 & 0.04 & -0.02 & 0.10 \\
\hline $\begin{array}{l}\text { Friend } \\
\text { exclusivity }\end{array}$ & -0.11 & 0.10 & $0.25 * *$ & -0.07 & 0.06 & $0.29 * *$ \\
\hline $\begin{array}{l}\text { Friend } \\
\text { betrayal }\end{array}$ & -0.003 & 0.03 & $0.16 * *$ & 0.03 & 0.02 & $0.24 * *$ \\
\hline $\begin{array}{l}\text { Pro-social } \\
\text { behaviors }\end{array}$ & $0.18 * *$ & $-0.17 * *$ & $-0.13 *$ & $0.19 * *$ & $-0.15 *$ & $-0.17 * *$ \\
\hline
\end{tabular}


Table 6

Analysis of Relational Experiences and Attachment Styles in Friendships

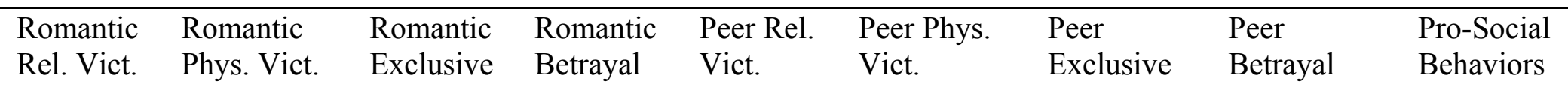

\begin{tabular}{|c|c|c|c|c|c|c|c|c|c|}
\hline Secure & $2.10(1.18)$ & $1.27(0.75)^{\mathrm{a}}$ & $2.75(1.11)$ & $1.88(0.71)$ & $3.28(1.33)$ & $1.78(0.97)$ & $2.44(0.93)^{\mathrm{ab}}$ & $2.35(0.64)^{\mathrm{ab}}$ & $5.74(0.69)^{\mathrm{a}}$ \\
\hline Dismissing & $2.08(1.00)$ & $1.29(0.77)^{\mathrm{a}}$ & $2.92(1.14)$ & $1.80(0.67)$ & $3.10(1.51)$ & $1.76(0.98)$ & $2.27(0.92)^{\mathrm{a}}$ & $2.21(0.65)^{\mathrm{a}}$ & $5.49(0.64)^{b}$ \\
\hline Preoccupied & $2.65(1.08)$ & $2.00(1.59)^{b}$ & $2.91(1.58)$ & $2.34(0.62)$ & $3.81(1.53)$ & $2.03(1.03)$ & $3.13(1.33)^{b}$ & $2.85(0.73)^{b}$ & $4.85(1.40)^{\mathrm{c}}$ \\
\hline Undifferentiated & $2.18(1.00)$ & $1.68(1.16)^{\mathrm{ab}}$ & $2.86(1.30)$ & $2.08(0.74)$ & $3.14(1.25)$ & $1.96(1.06)$ & $2.42(0.93)^{\mathrm{ab}}$ & $2.36(0.63)^{\mathrm{ab}}$ & $5.28(0.96)^{\mathrm{bc}}$ \\
\hline $\mathrm{F}$ & 0.937 & 4.225 & 0.560 & 2.873 & 1.212 & 0.512 & 3.312 & 4.161 & 9.517 \\
\hline $\mathrm{Df}$ & 3.334 & 3,334 & 3,334 & 3,381 & 3,379 & 3,380 & 3,380 & 3,386 & 3,380 \\
\hline $\mathrm{P}$ & 0.423 & 0.006 & 0.642 & 0.036 & 0.305 & 0.674 & 0.020 & 0.006 & $<0.001$ \\
\hline
\end{tabular}


Table 7

Analysis of Relational Experiences and Attachment Styles in Romantic Relationships

\begin{tabular}{|c|c|c|c|c|c|c|c|c|c|}
\hline & $\begin{array}{l}\text { Romantic Rel. } \\
\text { Vict. }\end{array}$ & $\begin{array}{l}\text { Romantic } \\
\text { Phys. Vict. }\end{array}$ & $\begin{array}{l}\text { Romantic } \\
\text { Exclusive }\end{array}$ & $\begin{array}{l}\text { Romantic } \\
\text { Betrayal }\end{array}$ & $\begin{array}{l}\text { Peer Rel. } \\
\text { Vict. }\end{array}$ & $\begin{array}{l}\text { Peer Phys. } \\
\text { Vict. }\end{array}$ & $\begin{array}{l}\text { Peer } \\
\text { Exculsive }\end{array}$ & Peer Betrayal & $\begin{array}{l}\text { Pro-social } \\
\text { Behaviors }\end{array}$ \\
\hline Secure & $1.98(1.10)^{\mathrm{a}}$ & $1.22(0.63)^{\mathrm{a}}$ & $2.85(1.12)^{\mathrm{a}}$ & $1.86(0.70)$ & $3.25(1.39)$ & $1.66(0.83)^{\mathrm{a}}$ & $2.34(0.91)^{\mathrm{a}}$ & $2.32(0.66)^{\mathrm{ab}}$ & $5.67(0.68)^{\mathrm{a}}$ \\
\hline Dismissing & $2.46(1.10)^{b}$ & $1.50(1.17)^{\mathrm{ab}}$ & $2.49(0.91)^{\mathrm{a}}$ & $2.02(0.72)$ & $3.26(1.39)$ & $2.14(1.33)^{b}$ & $2.22(0.78)^{\mathrm{a}}$ & $2.30(0.58)^{\mathrm{ab}}$ & $5.58(0.72)^{\mathrm{a}}$ \\
\hline Preoccupied & $2.65(0.95)^{\mathrm{ab}}$ & $1.79(1.51)^{\mathrm{ab}}$ & $3.86(1.66)^{b}$ & $2.30(0.72)$ & $3.91(1.31)$ & $1.76(0.92)^{\mathrm{ab}}$ & $3.60(1.23)^{b}$ & $2.75(0.57)^{\mathrm{a}}$ & $5.61(0.70)^{a b}$ \\
\hline Undifferentiated & $2.35(1.14)^{\mathrm{ab}}$ & $1.72(1.10)^{b}$ & $2.70(1.33)^{\mathrm{a}}$ & $1.76(0.69)$ & $2.89(1.42)$ & $2.14(1.17)^{b}$ & $2.64(1.00)^{\mathrm{a}}$ & $2.20(0.70)^{b}$ & $5.16(1.11)^{b}$ \\
\hline $\mathrm{F}$ & 4.296 & 5.299 & 4.890 & 2.822 & 1.770 & 5.812 & 10.166 & 2.530 & 5.037 \\
\hline df & 3,335 & 3,335 & 3,335 & 3,381 & 3,376 & 3,377 & 3,377 & 3,383 & 3,377 \\
\hline $\mathrm{p}$ & 0.005 & 0.001 & 0.002 & 0.039 & 0.152 & 0.001 & $<0.001$ & 0.057 & 0.002 \\
\hline
\end{tabular}


Figure 1. Interactions between biological sex and the mean scores for attachment style in romantic relationships.

Figure 2. Interactions between biological sex and the mean scores for attachment style in friendships 


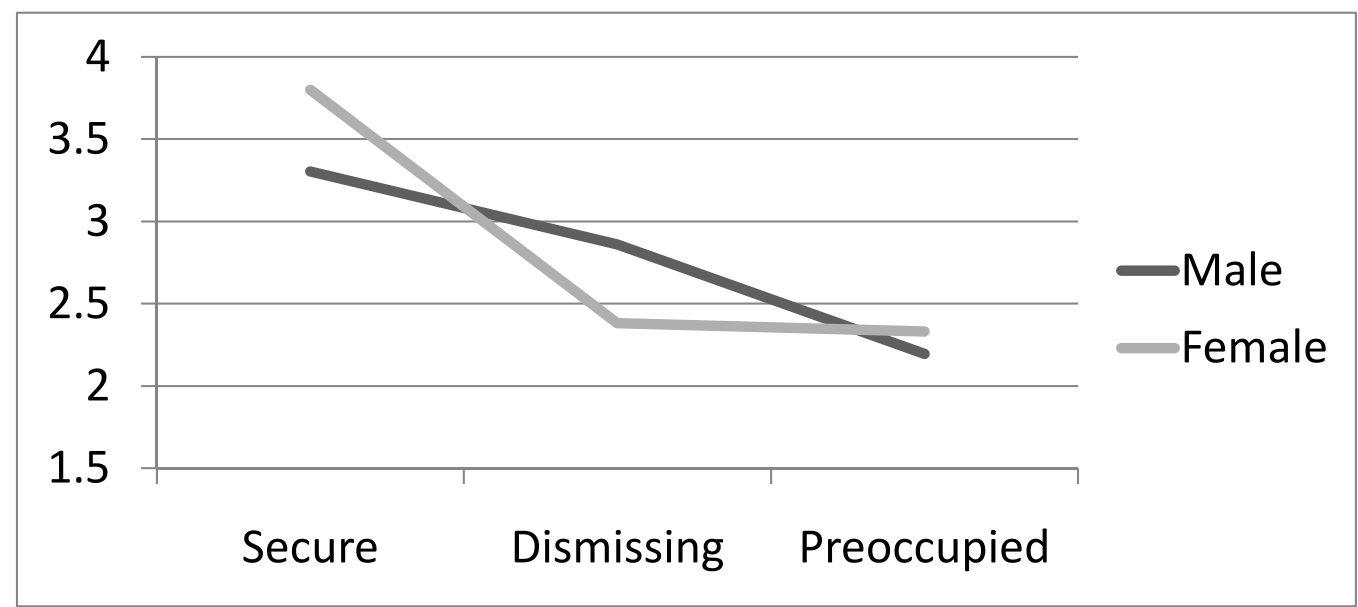




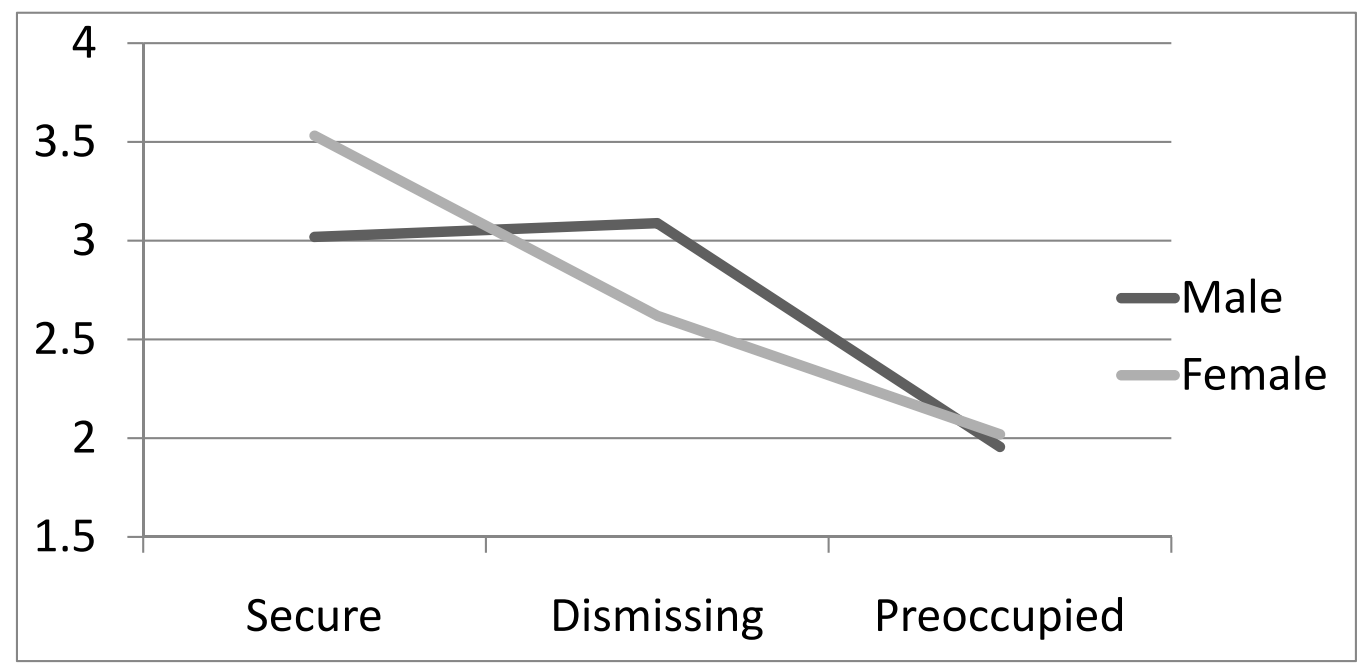

